\title{
Limnochemistry of the remote, high mountain Lake Marboré (Ordesa and Monte Perdido National Park, Central Pyrenees): Stratification dynamics and trace metal anomalies
}

\author{
Javier Sánchez-España1,*, M. Pilar Mata1, Juana Vegas², Mario Morellón³, Juan A. Rodrí- \\ guez $^{4}$, Ángel Salazar ${ }^{1}$ and Iñaki Yusta ${ }^{5}$ \\ ${ }^{1}$ Department of Geological Resources Research, Spanish Geological Survey (IGME), Calera, 1, 28760 Tres \\ Cantos, Madrid, Spain. \\ 2 Department of Geological Resources Research, Spanish Geological Survey (IGME), Ríos Rosas, 23, 28003 \\ Madrid, Spain. \\ 3 CITIMAC, Faculty of Science, University of Cantabria, Avenida de los Castros s/n, 39005 Santander (Canta- \\ bria), Spain. \\ ${ }^{4}$ Department of Geoscientific Infrastructure and Services, Spanish Geological Survey (IGME), Calera, 1, 28760 \\ Tres Cantos, Madrid, Spain. \\ 5 Department of Mineralogy and Petrology, University of the Basque Country (UPV/EHU), Apdo 644, Bilbao, \\ Spain. \\ * Corresponding author: j.sanchez@igme.es
}

Received: 26/10/16

Accepted: 07/11/17

\begin{abstract}
Limnochemistry of high mountain Lake Marboré (Central Pyrenees)

Lake Marboré (or Ibón de Marboré) is a high-altitude (2612 m a.s.l.) alpine lake situated in the central area of the Pyrenees range (NE Spain), which forms part of Ordesa and Monte Perdido National Park. This emblematic lake of glacial origin is chiefly fed by snow and meltwater, and the outlet is the headwaters of the Cinca River. Given the extreme climatic conditions prevailing in the area and the difficulty of sampling and monitoring due to the thick layer of ice and snow that covers the cirque most of the year, this lake has been the subject of very little scientific research. Although some paleolimnological studies have been performed on sediment cores, no previous investigation has been carried out on the limnology (including limnochemistry, stratification dynamics and microbial ecology) of this lake. This work presents the main findings and conclusions that have emerged from a recent study conducted in the lake over the course of three summer campaigns (2013 to 2015, always in September). We report the stratification dynamics and water chemistry of this lake (including the nutrient availability and trace metal dynamics), as well as basic parameters related to the biological activity, such as $\mathrm{O}_{2}$ consumption and redox chemistry. Our results show that Marboré is ultra-oligotrofic and hosts very low biological activity, typical of high mountain lakes. A slight stratification developed at the beginning of the ice-free period, with small vertical gradients in temperature $\left(3-11^{\circ} \mathrm{C}\right)$ and electrical conductivity $(60-100 \mu \mathrm{S} / \mathrm{cm}$ ) between the bottom (situated at approximately $28 \mathrm{~m}$ depth) and the lake surface. The current $\mathrm{pH}$ (between 7.0 and 7.8, which is lower than previous measurements) is not compatible with the formation of calcite in the water column. This finding is coherent with the mineralogy of the sedimentary record. The most interesting geochemical finding, however, relates to the presence of significant concentrations of dissolved trace metals (Fe and $\mathrm{Zn}$ ) and sulfate, along with suspended mineral particles (including sulfates), near the thermocline. These high concentrations suggest that local sulfide oxidation processes influence the lake chemistry.
\end{abstract}

Key words: High mountain lakes, calcite, sulfide oxidation, sulfates, trace metals, Pyrenees 


\section{RESUMEN}

\section{Limnología química del lago de alta montaña de Marboré (Pirineos centrales)}

El lago o ibón de Marboré es un lago alpino de alta montaña (2612 m.s.n.m.), situado en el área central de los Pirineos (NE de España), que forma parte del Parque Nacional de Ordesa y Monte Perdido. Este emblemático lago de origen glacial se alimenta principalmente de nieve y aguas de fusión, y su arroyo emisario da origen al río Cinca. Las condiciones climáticas extremas que se dan en esta zona y las dificultades para muestrear y monitorizar, debido a la gruesa capa de hielo y nieve que cubre este circo glaciar durante la mayor parte del año, han hecho que este lago no haya sido investigado en profundidad hasta el momento. Aunque existían algunos estudios paleolimnológicos mediante sondeos, hasta ahora no se había investigado su limnología (incluyendo limnoquímica, dinámica de estratificación y ecología microbiana). Este trabajo presenta los principales descubrimientos y conclusiones de un estudio llevado a cabo en el lago durante tres campañas estivales consecutivas (2013 a 2015, siempre en septiembre). Se describe su dinámica de estratificación y su hidroquímica (incluyendo la disponibilidad de nutrientes y la dinámica de metales pesados), así como los parámetros básicos relacionados con la actividad biológica, como el consumo de oxígeno y la química redox. Nuestros resultados demuestran que Marboré es un lago ultra-oligotrófico y alberga una reducida actividad biológica, típico de lagos de alta montaña. Al comienzo del periodo de deshielo se desarrolla una ligera estratificación, con pequeños gradientes verticales de temperatura $\left(3-11^{\circ} \mathrm{C}\right)$ y conductividad eléctrica $(60-100$ $\mu \mathrm{S} / \mathrm{cm}$ ) entre el fondo (situado a aproximadamente $28 \mathrm{~m}$ de profundidad) y la superficie del lago. El pH actual (entre 7.0 y 7.8, inferior a medidas previas) no es compatible con la formación de calcita en la columna de agua, resultado coherente con la mineralogía del registro sedimentario. El resultado geoquímico más interesante es, sin embargo, la presencia de concentraciones significativas de metales traza disueltos (Fe y $\mathrm{Zn}$ ) y sulfatos, junto con partículas minerales en suspensión (incluidos sulfatos), cerca de la termoclina. Estas altas concentraciones sugieren que la oxidación local de sulfuros influye sobre la química del lago.

Palabras clave: Lagos de alta montaña, calcita, oxidación de sulfuros, sulfatos, metales traza, Pirineos

\section{INTRODUCTION AND OBJECTIVES}

High mountain lakes are extremely vulnerable ecosystems that have been relatively preserved from direct human activities, such as cattle grazing, industry, and mining (Catalán et al., 2006, 2013). Despite their remote geographical location, the pristine state of high mountain lakes has been changing recently due to global and local stressors, such as climate change, energy production, fisheries, and outdoor activities, including tourism (Arnaud et al., 2004; Catalán et al., 2006; Toro et al., 2006; Thévenon et al., 2011, Anselmetti et al., 2007). Some of these remote lakes and peatbogs have been polluted by increased nutrients, trace metals or persistent organics via atmospheric deposition and runoff since the Roman period (Martínez-Cortizas et al., 1987, 1999; Sickman et al., 2003; Camarero et al., 1998, 2017; García-Alix et al., 2013; Corella et al., 2017; Hillman et al., 2017), showing the large-scale impact of activities such as mining, smelting and industrial processes on the environment. Acid deposition is thought to be the most potent threat on European mountain lakes, though the influence of acids, nutrients, trace metals and trace organics in the context of global warming presents a big scientific challenge (Wathne et al., 1997).

Regional surveys in the Pyrenees did not find evidence of lake acidification (Catalán et al., 1993), though more recent studies have sown moderate acidification of surface waters in Pyrenean lakes in relation with either burning of fossil fuels (Camarero \& Catalán 1998) and/or increased nitrogen loadings (e.g., Curtis et al., 2005). Thus, the evolution of the $\mathrm{pH}$ of surficial waters in high mountain lakes is of great environmental interest.

According to climatic models, temperature in these lakes will increase due to climate change, and this will have significant consequences on the epilimnetic temperature and the duration of snow cover. These parameters have both indirect effects on biogeochemical cycles (Mooij et al., 2007). Therefore, high-quality limnological data and a precise characterization of the watershed are necessary to evaluate the response of high mountain lakes to global change. These studies need to consider different aspects, such as the following: (i) the nature of the inputs, (ii) the geochemical background of trace metals, (iii) the nature of the soil, and (iv) the geological process- 
es at the catchment scale (e.g., weathering mechanisms, weathering rates, and surface hydrology).

This study focused on the global changes in the high mountain lakes of Spanish national parks. The objective of this research was to assess the geochemical and limnological dynamics of Lake Marboré, a remote lake in a high mountain environment with no previous hydrochemical information available. Based on an interannual study of the stratification dynamics and water chemistry, we focused on some key limnochemical aspects including the following: (i) the trophic state of the lake, (ii) $\mathrm{pH}$ evolution, and (iii) trace metal dynamics. In addition of providing a thorough hydrochemical framework for ongoing paleolimnological and ecological studies in this lake, the geochemical and limnological data obtained will allow for the assessment of the main parameters that need to be monitored in any future, long-term ecological research programmes.

\section{ENVIRONMENTAL SETTING}

Lake Marboré (4241'44" N, $0^{\circ} 2^{\prime} 24^{\prime \prime} \mathrm{E}$ ) is in Ordesa and Monte Perdido National Park, in the central part of the Pyrenees (north-eastern Spain). The lake is close to Monte Perdido Peak and its associated glacier (3355 $\mathrm{m}$ a.s.l.), which is one of the last relict glaciers in southern Europe. Local landforms are controlled by the geological structure (lithology, faults), the glacier and karstic processes (Hernández-Pacheco \& Vidal-Box, 1946; Nicolás-Martínez, 1981, Garcia-Ruiz et al., 2014). The Marboré cirque lies on a Cretaceous carbonate-limonite and sandstone substrate, and a set of moraines of different ages are present on the southern side. There is no hydrological connection between the lake and the glacier, although historical data from the 19th and 20th centuries showed a permanent snowfield draining to the northern border of the lake.

The mean annual temperature recorded by the nearby meteorological station at Góriz (2220 m a.s.l.) for the period of $1982-2001$ was $4.9 \pm 0.5$ ${ }^{\circ} \mathrm{C}$. Precipitation (annual average of $1850 \mathrm{~mm}$ ) occurs mostly in the autumn and spring. Some studies have noted a decrease in winter snow precipitation during the last few decades and an accelerated decrease in the glacial surface

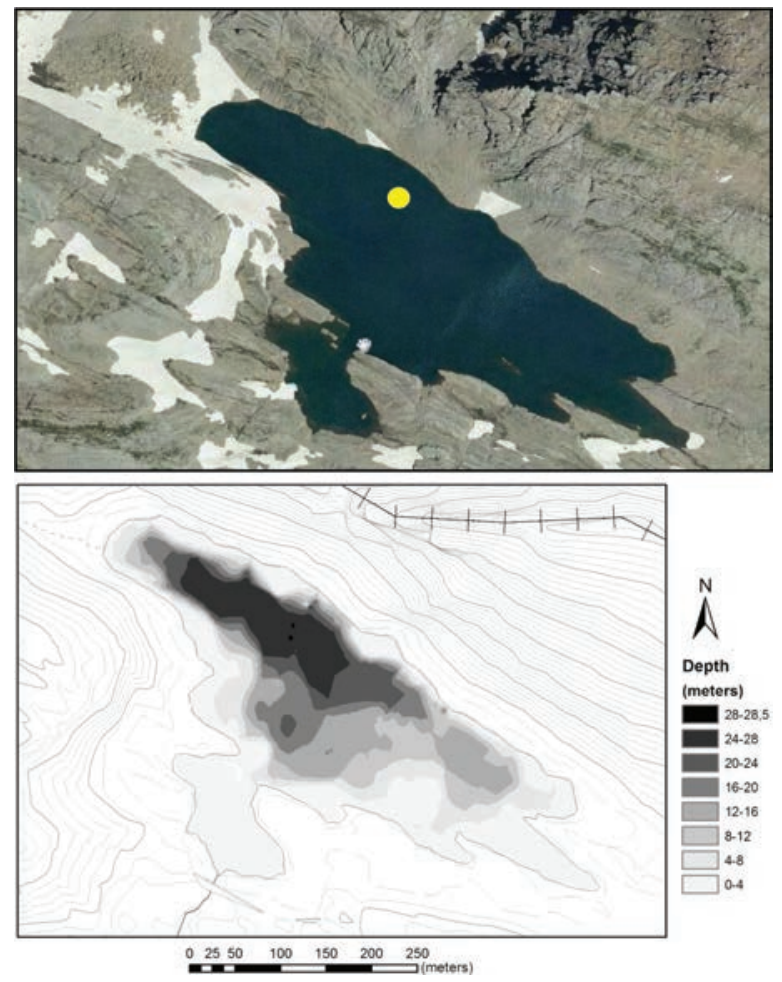

Figure 1. Satellite image (Google Earth, top) and bathymetric map (bottom) of the post-glacial, high mountain Lake Marboré; the yellow point marks the position of the mooring line with the thermistors; water sampling and physico-chemical profiling were also conducted in this site. Imagen satélite (Google Earth, arriba) y mapa batimétrico (abajo) del lago de alta montaña post-glaciar de Marboré; el punto amarillo indica la posición de la línea de fondeo con los termistores; el muestreo de aguas y los perfiles físico-químicos también fueron realizados en este mismo punto.

(López-Moreno, 2005). The lake water level during the summer is regulated by an outlet at the southern border (García-Ruiz et al., 2016). The lake receives runoff and sediment inputs from the northern and north-eastern areas.

Presently, there is very little information available on the lake chemistry. Scarce data from the surface were obtained by the Ebro Hydrographic Watershed Authority between 2005 and 2012 (e.g., 0.2 mg/L N-NO $3^{-}, 0.2$ mg/L $\mathrm{NH}_{4}, 9 \mu \mathrm{g} / \mathrm{L}$ total P, $0.65 \mu \mathrm{g} / \mathrm{L}$ Chl- $a$, biovolume of $0.71 \mathrm{~mm} / \mathrm{L}$ and Secchi disc of $6.2 \mathrm{~m})$. These data suggest that the lake is (ultra-)oligotrophic (CHE, 2006, 2013). No benthic species have been described, and arboreal vegetation is absent around the lake (the treeline is located at approximately $2000 \mathrm{~m}$ a.s.l.). 
The soils are permafrost, and the surface layer thaws in the summer, forming an active layer (mollisol) (García-Ruiz et al., 2014).

\section{METHODS}

\section{Morphometric and bathymetric analysis of the lake basin}

A detailed bathymetric survey was conducted in 2013 using Garmin geographic positioning systems and Hummingbird eco-sounders operated from a rubber boat. A bathymetric map was built with X, Y, Z data in ESRI Arc Info 9.3 (Fig. 1).

\section{Field work: Geochemical profiling and water sampling}

Field campaigns were conducted over the course of three consecutive years (2013-2015, always in September). The physicochemical parameters were obtained with a Hydrolab MS5 multi-parametric datasonde (Hach $\left.{ }^{\circledR}\right)$ and include temperature, $\mathrm{T}$; specific conductance, $\mathrm{SpC}$; $\mathrm{pH}$; redox potential, ORP; dissolved oxygen concentration,
DO; and total pressure of dissolved gases, TDG. In addition, T data loggers (HOBO U24 from Onset Computer Corporation) were installed at different depths on a mooring line situated in the deepest area of the lake (Fig. 1). Five thermistors (at depths of $0.5,5,10,15$ and $25 \mathrm{~m}$ ) were left in the lake during the period 2013-2015 to record T changes at 2-hour intervals. The measuring range and resolution of the thermistors were $0-40{ }^{\circ} \mathrm{C}$ and $0.1{ }^{\circ} \mathrm{C}$, respectively. The recorded data were transferred to a laptop and analysed with HOBOWare Pro 3.7.1 software. Water samples for chemical analyses of major ions, carbon and nutrient concentrations were taken from different depths with a Van Dorn ${ }^{\circledR}$ sampling bottle (KC Denmark). Samples for chemical analyses were filtered on site with $0.45 \mu \mathrm{m}$ nitrocellulose membrane filters (Millipore $\left.{ }^{\circledR}\right)$, stored in polyethylene bottles (125-250 $\mathrm{mL}$ ), and cool preserved during transport. Samples for cation analyses were acidified with $\mathrm{HNO}_{3}$.

\section{Chemical analyses of waters}

Chemical analyses were conducted with different techniques, including ion chromatography and a

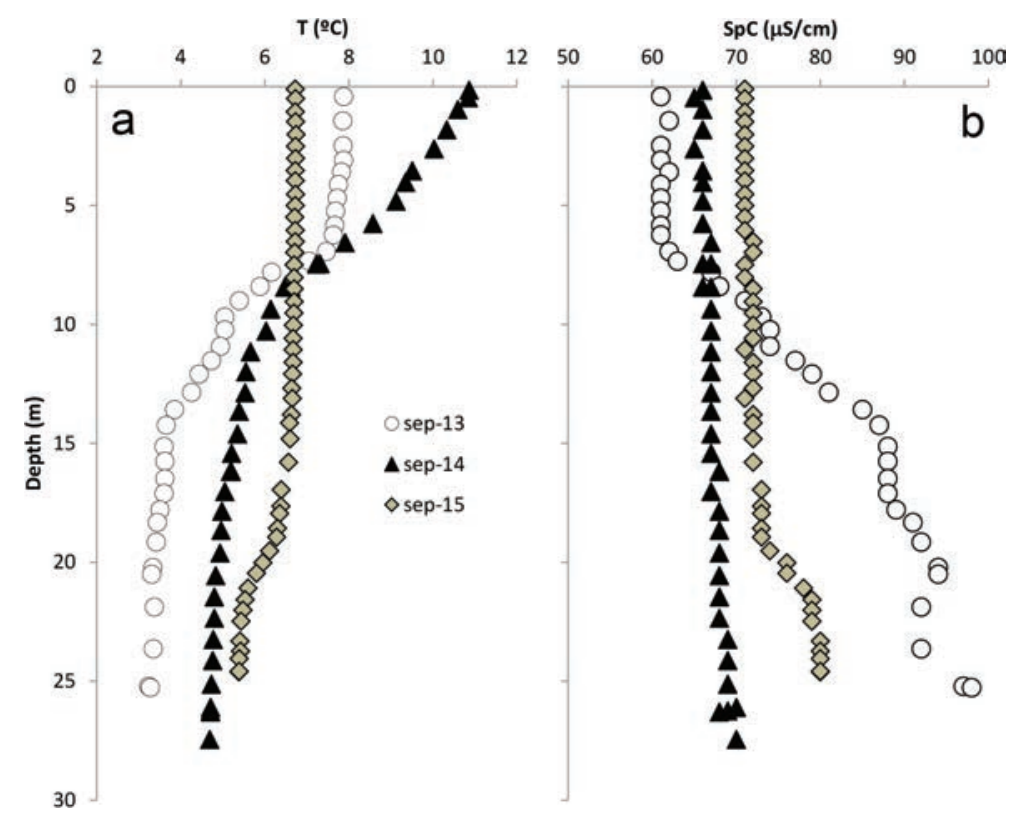

Figure 2. Depth profiles of temperature (T) (a) and specific conductance (SpC) (b) measured in Lake Marboré for three consecutive summer seasons. Perfiles verticales de temperatura (T) (a) y conductividad específica (SpC) (b) medidas en el Lago Marboré en tres temporadas estivales consecutivas. 
continuous flow autoanalyzer for major anions $\left(\mathrm{SO}_{4}{ }^{2-}, \mathrm{NO}_{3}-, \mathrm{NO}_{2}-, \mathrm{PO}_{4}{ }^{3-}, \mathrm{HCO}_{3}{ }^{-}, \mathrm{CO}_{3}{ }^{2-}\right)$, total organic carbon (TOC), ammonia $\left(\mathrm{NH}_{4}^{+}\right)$and silica $\left(\mathrm{SiO}_{2}\right)$. Atomic absorption spectrometry and inductively coupled plasma-mass spectrometry (ICP-MS) were used for major cations (e.g., Ca, $\mathrm{Mg}, \mathrm{Na}, \mathrm{K}$ ) and trace metals (e.g., $\mathrm{Fe}, \mathrm{Mn}, \mathrm{Cu}, \mathrm{Zn}$, $\mathrm{As}, \mathrm{Cr}, \mathrm{Pb}, \mathrm{Cd}$ ), although only a few relevant elements will be discussed here. Total phosphorus was measured with a DR2800 UV-VIS spectrophotometer (Hach), using the LCS 349 method with previous acid digestion in $11 \%$ sulfuric acid.

\section{Stable isotopic analyses of water samples}

Oxygen and hydrogen isotopic analyses of water samples were carried out at the Stable Isotope Laboratory of the Universidad Autónoma de Madrid (Cantoblanco, Madrid). The $\delta 18 \mathrm{O}$ and $\delta$ ${ }_{2}^{2} \mathrm{H}$ measurements were measured in VG Isoprep 18, EA Thermo 1108 HT and/or Gas Bench Thermo equipment coupled with an IRMS VG Prism II. The analytical precision for this dataset was approximately $\pm 0.1 \%$ for $\delta 18 \mathrm{O}$ values and $\pm 1 \%$ for $\delta^{2} \mathrm{H}$ values.

\section{Chemical and mineralogical analyses of suspended mineral particles}

Suspended mineral particles obtained by the filtration $(\varnothing>0.45 \mu \mathrm{m})$ of waters from different depths, in addition to coarser mineral particles found in the snow around the lake, were studied by X-ray Fluorescence (XRF), X-ray diffraction (XRD), optical microscopy, field emission scanning electron microscopy (FESEM-EDS) and ICP-MS. These analyses were conducted either directly on the filters or on previously separated mineral particles obtained after the sonication (5 min) of filters in an ethanol bath.

\section{RESULTS}

\section{Stratification}

The temperature profiles shown in Figure 2a illustrate a variable thermal stratification depending on the time elapsed between the melting of the ice cover and the moment of sampling. In September 2015, the temperature gradient between the surface $\left(\sim 7^{\circ} \mathrm{C}\right)$ and the bottom $(\sim 5.5$

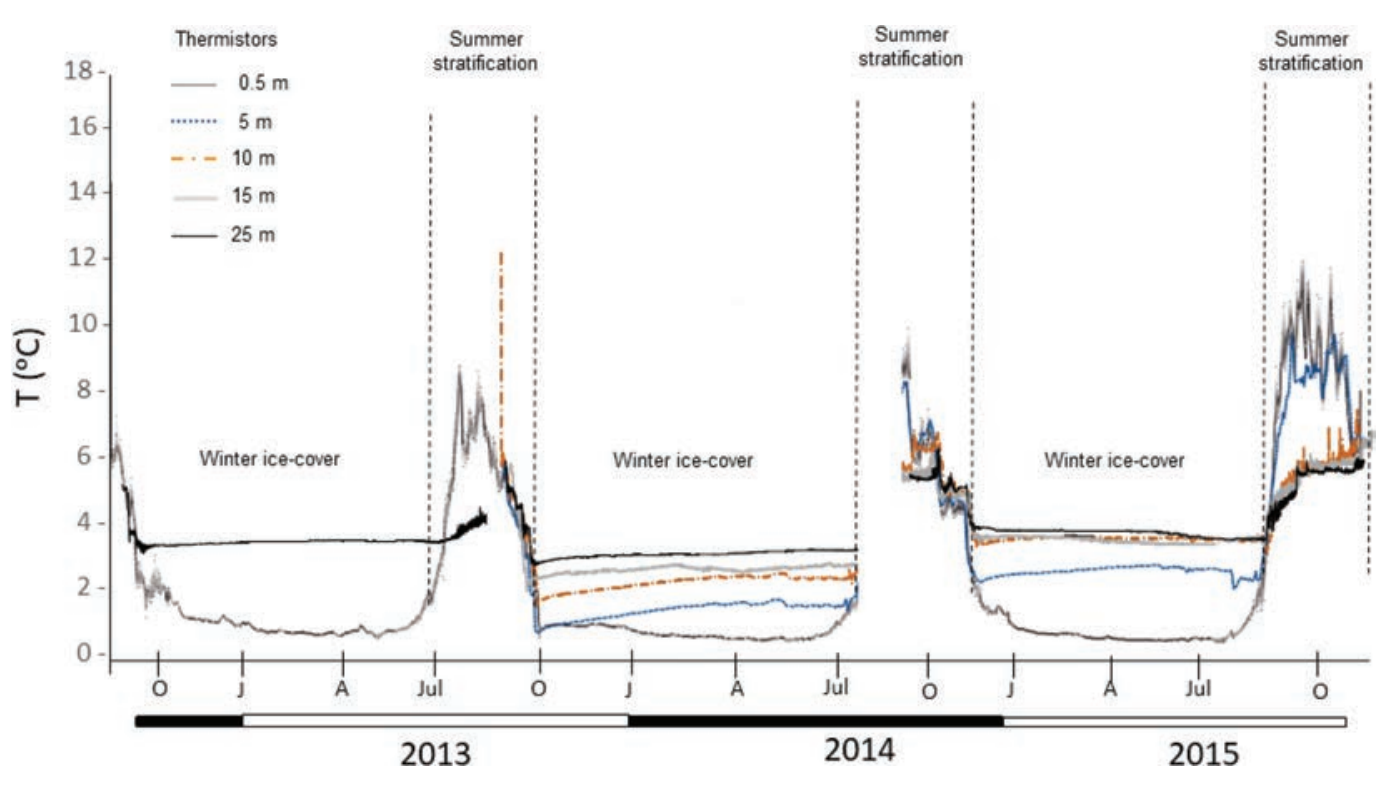

Figure 3. Temperature records of Lake Marboré at different depths (surface, $5 \mathrm{~m}, 10 \mathrm{~m}, 15 \mathrm{~m}$ and lake bottom) as measured by thermistors during the period of 2012-2015. Registros de temperatura en el Lago Marboré a diferentes profundidades (superficie, 5 m, 10 m, 15 m y fondo del lago) medidos por termistores durante el periodo 2012-2015. 
${ }^{\circ} \mathrm{C}$ ) was very small, whereas in September 2014, a marked thermal stratification was observed (epilimnion of $\mathrm{T}=11{ }^{\circ} \mathrm{C}$ and hypolimnion of 4.5 ${ }^{\circ} \mathrm{C}$ ). The situation in September 2013 was intermediate (Fig. 2a). Like many other mountain lakes in the northern hemisphere, this lake should start losing heat around August (depending on prevalent weather conditions), when direct sunlight is usually decreasing. The observed $\mathrm{T}$ profiles should thus illustrate the onset of the thermocline deepening process.

The profiles of specific conductance also showed a differing stage of the lake stratification. The profiles from 2014 and 2015 (65-70 $\mu \mathrm{S} / \mathrm{cm}$ and $70-80 \mu \mathrm{S} / \mathrm{cm}$ ) showed a very small difference in the total dissolved solids content throughout the water column. Conversely, the difference observed in 2013 between the epilimnion $(60 \mu \mathrm{S} / \mathrm{cm})$ and
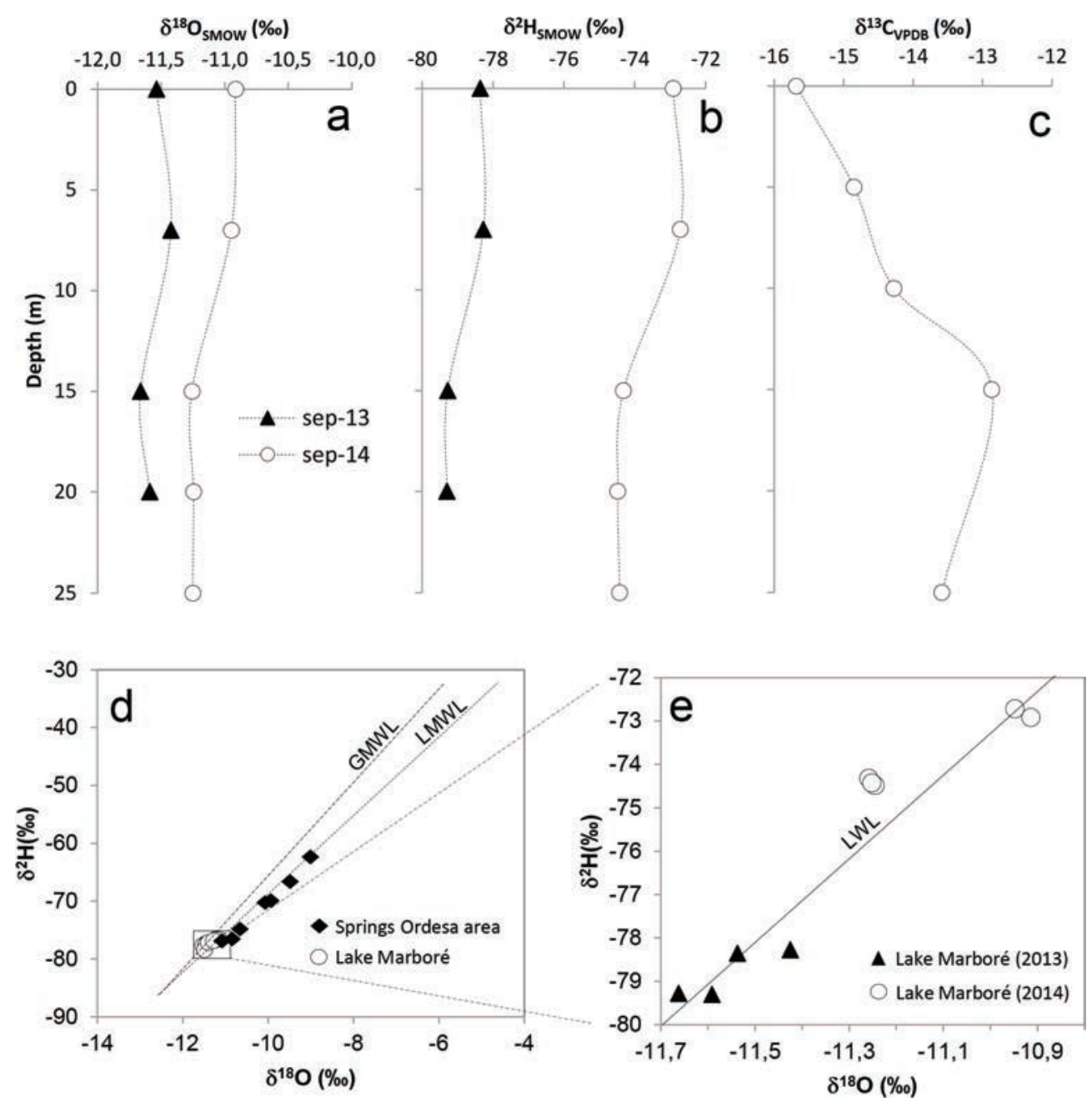

Figure 4. Isotopic profiles for Lake Marboré: (a) oxygen ( $\left.\delta^{18} \mathrm{O}_{\mathrm{SMOW}}\right)$, (b) hydrogen $\left(\delta^{2} \mathrm{H}_{\mathrm{SMOW}}\right)$ and (c) dissolved inorganic carbon $\left(\delta^{13} \mathrm{C}_{\mathrm{VPDB}}\right)$. (d-e) Binary plots of $\delta^{18} \mathrm{O}_{\text {SMOW }}$ against $\delta^{2} \mathrm{H}_{\text {SMOW }}$ for Marboré Lake (same data as in a-b). Data from nearby springs from the Ordesa area (from Lambán et al., 2015) have also been included for comparison. Abbreviations: GMWL, global meteoric water line (as defined by Rozanski et al., 1993); LMWL, local meteoric water line; LWL, lake water line. Perfiles isotópicos del Lago Marboré: (a) Oxígeno ( $\left.\delta^{18} \mathrm{O}_{S M O W}\right)$, (b) Hidrógeno ( $\left.\delta^{2} H_{S M O W}\right)$ y (c) carbono inorgánico disuelto ( $\left.\delta^{13} C_{V P D B}\right)$. (d-e) Diagramas binarios de $\delta^{18} \mathrm{O}_{S M O W}$ vs. $\delta^{2} \mathrm{H}_{S M O W}$ para el Lago Marboré (mismos datos que en $a-b$ ). Se incluyen también datos de manantiales cercanos del área de Ordesa (tomados de Lambán et al., 2015) con fines comparativos. Abreviaturas: GMWL, línea de agua meteórica global (Rozanski et al., 1993); LMWL, línea de agua meteórica local; LWL, línea de agua del lago. 
the hypolimnion $(100 \mu \mathrm{S} / \mathrm{cm})$ was significant.

The $\mathrm{T}$ and $\mathrm{SpC}$ profiles from 2013 show a "staircase-like" profile with different sublayers of decreasing temperature and increasing conductivity with depth. This situation is usually diagnostic of double-diffusive convection, where both heat and solute gradients exist at differing rates across the water column (Boehrer, 2012).

The records obtained from the thermistors for the period of 2013-2015 indicate that the lake is dimictic and shows long periods (usually lasting from November to the end of July) of inverse thermal stratification below the ice cover $\left(0{ }^{\circ} \mathrm{C}\right.$ near the surface and $3{ }^{\circ} \mathrm{C}$ at the lake bottom; Fig. 3 ), alternating with short periods (approximately 2-3 months, August-October) of forward stratification during the late summer and early fall. These $\mathrm{T}$ records also show variable fluctuations in the maximum temperature at the lake surface during the summer, ranging from $9-10{ }^{\circ} \mathrm{C}(2013)$ to $17-18{ }^{\circ} \mathrm{C}$ (2014-2015). The beginning of ice melting usually occurred in July, in accordance with observations in other remote mountain lakes in Europe (e.g., Catalán et al., 2002).

\section{Stable isotopes}

The $\delta^{18 \mathrm{O}}$ and $\delta^{2} \mathrm{H}$ profiles obtained in 2013 and 2014 show very little variation through the water column (Fig. 4a-b). The existence of two overturn periods in this dimictic lake aids in reducing the vertical gradients in stable isotope values across the water column. This low vertical variation also indicates negligible fractionation because of very low evaporation, which is coherent with the low temperatures of this high-altitude mountainous region and with the existence of a protective ice cover during 9-10 months a year.

The values obtained for the lake water $\left(\delta 18 \mathrm{O}_{\mathrm{S}-}\right.$ MOW $=-11$ to $-11.5 \%$ and $\delta^{2} \mathrm{H}_{\text {SMOW }}=-78$ to -73 $\%$ ) match the values reported for groundwater and springs in the Ordesa area (Fig. 4d-e). The groundwater and springs are fed mainly by meteoric waters infiltrating the carbonate rocks (Lambán et al., 2015). The local meteoric water line (LMWL) is defined by the lake and spring waters and differs only slightly from the global meteoric water line (GMWL; Fig. 4d). Within the lake water line (LWL), small differences exist between 2013 and 2014 (Fig. 4e).

The $\delta 13 \mathrm{C}$ signature of dissolved inorganic carbon (-15.7 to $-12.9 \%$ \%; Fig. 4c) shows small vertical variations that could be the result of differences in the relative contribution of microbial respiration and mineralization with respect to abiotic calcite dissolution.

\section{Oxygen content and redox chemistry}

The distribution of dissolved oxygen in the lake differed significantly between 2013 and 2014 (Fig. 5a). No data could be recorded in 2015 due to a sensor failure, although the ORP values obtained in this campaign were intermediate between the other two and oxygen concentrations were likely intermediate between those measured in the previous years. In 2013, the lake showed significant oxygen subsaturation, which is indicative of a high biological and/or chemical oxygen demand. A slight vertical gradient was observed in this period between the lake surface (82 \% sat., equivalent to $9 \mathrm{mg} / \mathrm{L} \mathrm{O}_{2}$ ) and the lake bottom (59 \% sat., or 7.2 $\mathrm{mg} / \mathrm{L} \mathrm{O}_{2}$ ), which is consistent with more intense microbial respiration in deep waters and bottom sediments. In 2014, however, the water column was well oxygenated at all depths (105-120 \% sat., or 9-10.8 $\mathrm{mg} / \mathrm{L} \mathrm{O}_{2}$ ). A slight oxygen enrichment near the metalimnion suggested limited photosynthetic production by phytoplankton.

The profiles of ORP illustrate a varying chemical oxygen demand (Fig. 5b). The ORP was approximately $150 \mathrm{mV}$ in 2013 and approximately $450 \mathrm{mV}$ in 2014 (250-300 mV in 2015). The values from 2014 are typical of oxidizing and well-oxygenated environments, whereas the values of 2013 were more compatible with reducing conditions and with the presence of dissolved ferrous iron in the water column, as discussed below.

\section{pH and dissolved gases}

The pH profiles obtained in 2013 and 2014 showed significant vertical variations (Fig. 5c). In both periods, the $\mathrm{pH}$ was approximately 7.0-7.3 near the surface, increased to values of approximately 7.6-7.8 at depths of 9-12 $\mathrm{m}$, then decreased again to 7.1-7.3 above the 
sediment/water interface. This trend was not observed in 2015, when $\mathrm{pH}$ remained at approximately 7.2-7.5 at depths below $2 \mathrm{~m}$.

The TDG profiles exhibit increases in dissolved gas pressure at depth (Fig. 5d). In all cases, the TDG was approximately 550-560 $\mathrm{mmHg}$ near the lake surface and increased in the deepest 10 metres. In 2013, this parameter showed a linear shift to values of $680 \mathrm{mmHg}$ above the sediments, but the profiles of 2014 and 2015 exhibited a maximum at intermediate depths $(640-710 \mathrm{mmHg}$ at $16-20 \mathrm{~m})$ and decreased again near the lake bottom. These TDG variations cannot be related to the corresponding changes in dissolved oxygen concentration (Fig. $5 a$ ), and most likely indicate an increase of some

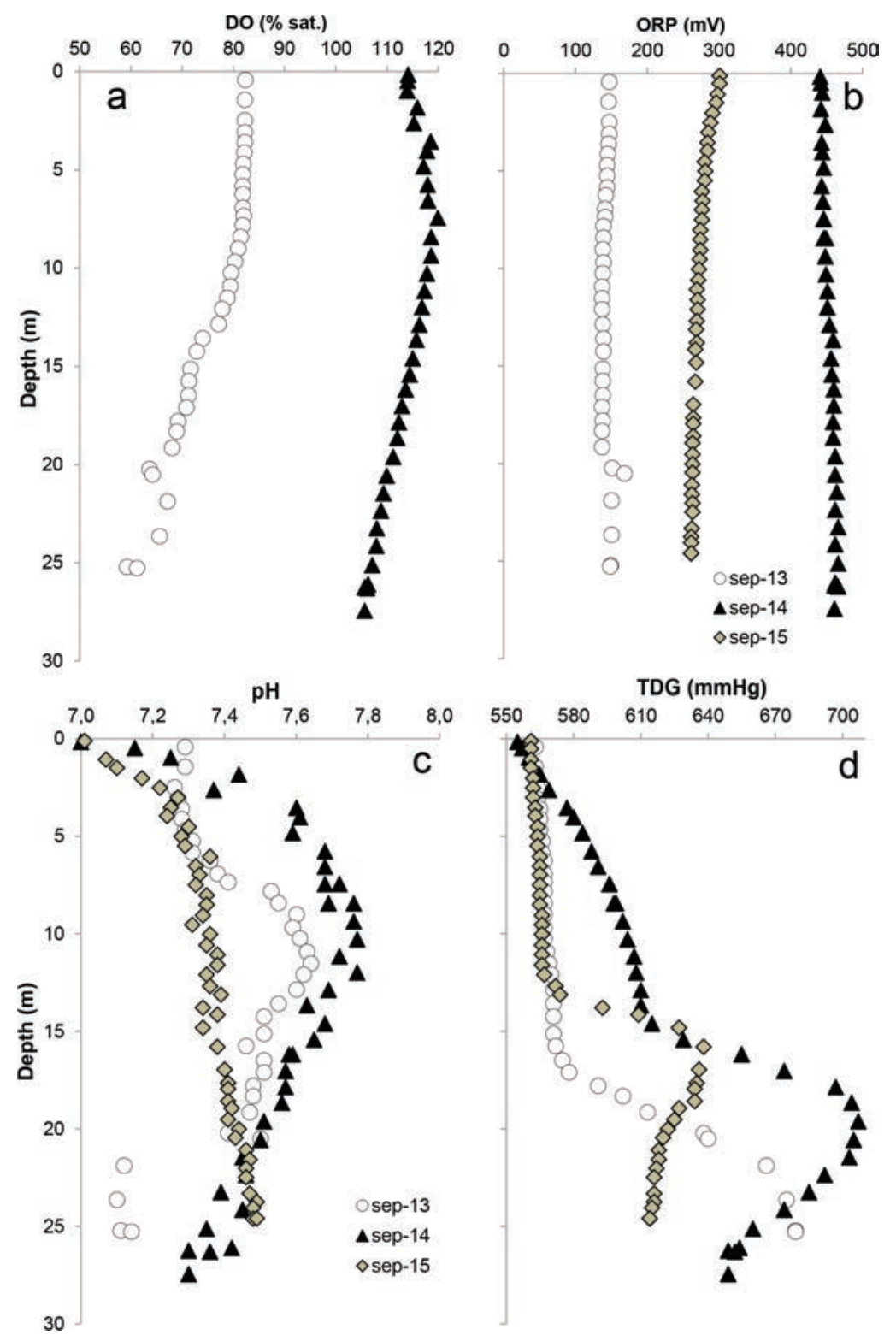

Figure 5. Depth profiles of dissolved oxygen (a), ORP (b), pH (c) and total dissolved gas (TDG) pressure (d) measured in Lake Marboré during the different summer seasons. Perfiles verticales de oxígeno disuelto (a), ORP (b), pH (c) y presión total de gas disuelto (TDG) (d) obtenidos en el Lago Marboré durante las tres campañas estivales consecutivas. 
other dissolved gas in the deep waters, most likely carbon dioxide $\left(\mathrm{CO}_{2}\right)$.

\section{Water chemistry}

\section{Anion concentration}

The dissolved inorganic carbon (DIC) in the analysed waters was exclusively bicarbonate (32-50 mg/L $\mathrm{HCO}_{3}$; Fig. 6a). The carbonate content was analytically undetectable in all cases, and the geochemical equilibrium calculations (see below) indicate that the amount of carbonic acid at $\mathrm{pH}>7.0$ should be negligible. A high positive correlation was found between the bicarbonate content and conductivity ( $r=0.97)$,
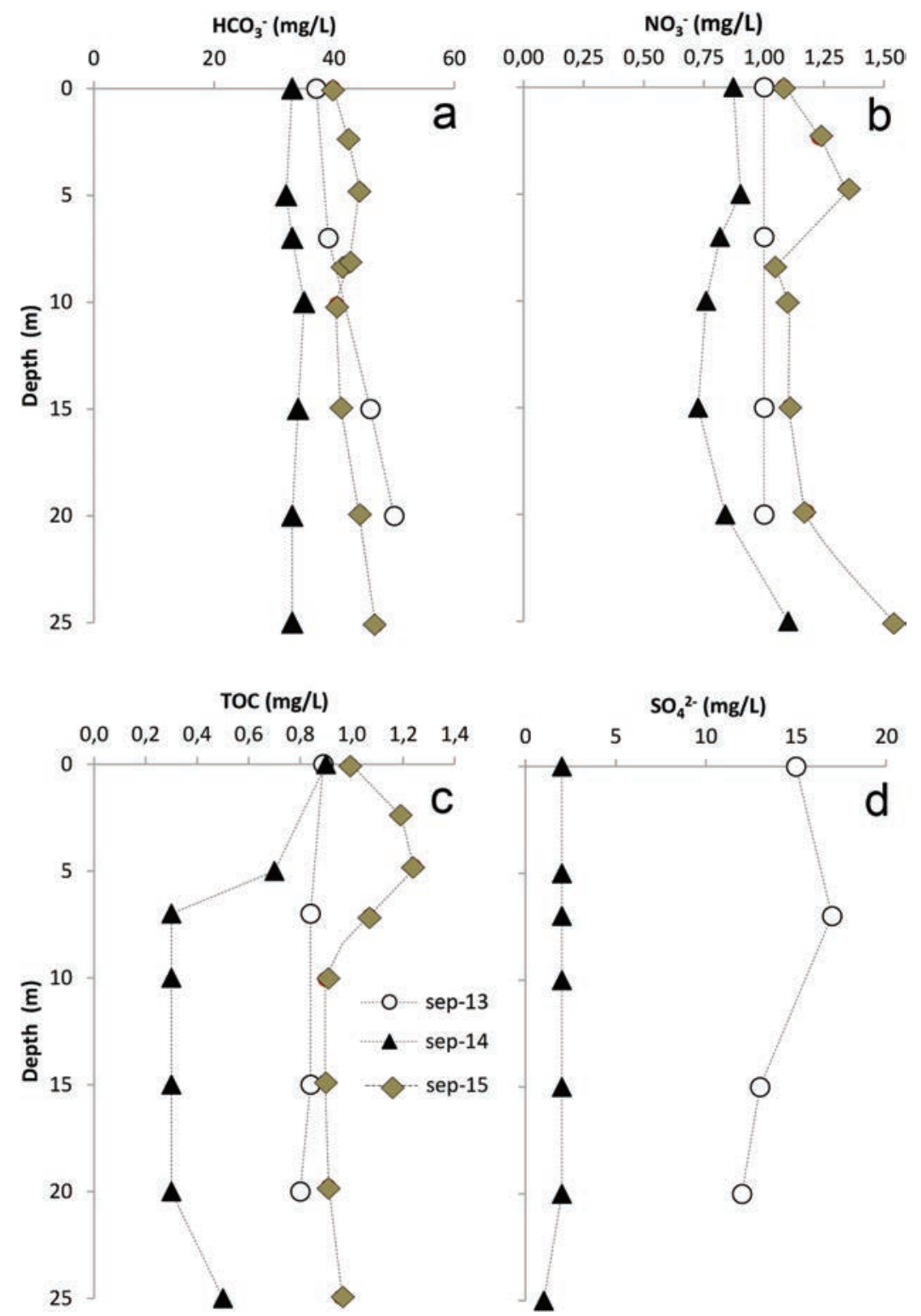

Figure 6. Depth profiles of bicarbonate $\left(\mathrm{HCO}_{3}^{-}\right)$(a), nitrate $\left(\mathrm{NO}_{3}^{-}\right)$(b), total organic carbon (TOC) (c) and sulfate ( $\left.\mathrm{SO}_{4}{ }^{2-}\right)(\mathrm{d})$ measured in Lake Marboré during three consecutive summer seasons. Perfiles verticales de bicarbonato ( $\left.\mathrm{HCO}_{3}^{-}\right)(\mathrm{a})$, nitrato ( $\left.\mathrm{NO}_{3}^{-}\right)$(b), carbono orgánico total (TOC) (c) y sulfato $\left(\mathrm{SO}_{4}{ }^{2-}\right)$ (d) obtenidos en el Lago Marboré durante las tres campañas estivales consecutivas. 
indicating the predominance of this major anion among the dissolved solids.

The concentrations of nitrate $\left(\mathrm{NO}_{3}{ }^{-}\right)$varied from $0.75 \mathrm{mg} / \mathrm{L}$ (2014) to $1.5 \mathrm{mg} / \mathrm{L}$ (2015) (Fig. $6 b)$. These values are significantly higher than those reported by CHE (2013) for the surface waters of this lake $\left(0.2-0.7 \mathrm{mg} / \mathrm{L} \mathrm{NO}_{3}\right.$ - for the period 2007-2009) and could be suggestive of recently increasing atmospheric input, as observed in other alpine lakes (Sickman et al., 2003; Mahowald, 2011). Nitrite was detected at very low concentrations (20-30 $\mu \mathrm{g} / \mathrm{L} \quad \mathrm{NO}_{2}{ }^{-}$). Phosphate and ammonium were always below the detection limit $\left(<20 \mu \mathrm{g} / \mathrm{L} \mathrm{PO}_{4}{ }^{3-;}<20 \mu \mathrm{g} / \mathrm{L} \mathrm{NH}_{4}+\right.$; not shown). Total phosphorus yielded very low values of 2-4 $\mu \mathrm{g} / \mathrm{L} \mathrm{P}_{\text {total }}$ in the surface waters and
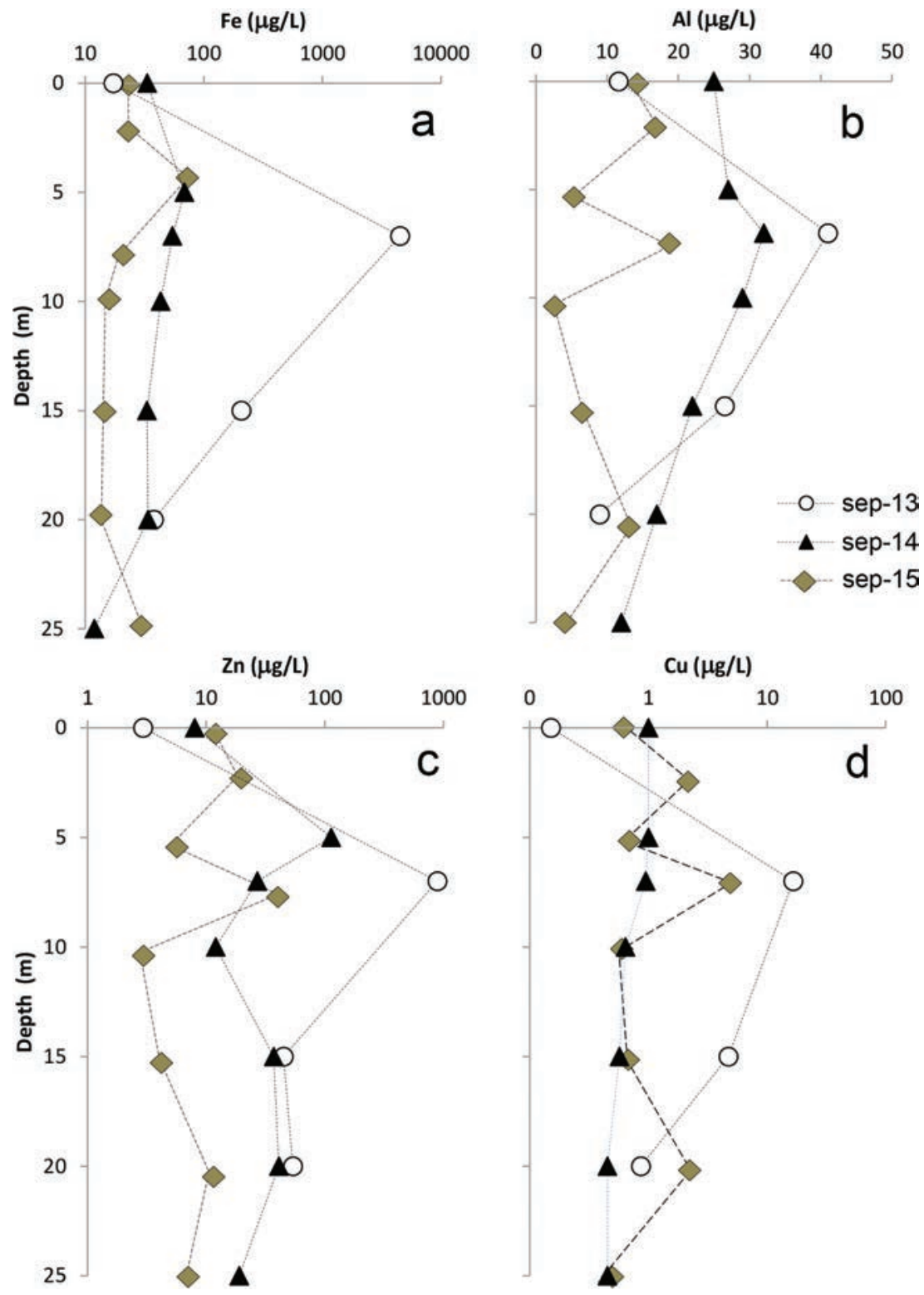

Figure 7. Depth profiles of total dissolved iron (a), aluminium (b), zinc (c) and copper (d) measured in Lake Marboré during three consecutive summer seasons. Perfiles verticales de hierro disuelto total (a), aluminio (b), zinc (c) y cobre (d) obtenidos en el Lago Marboré durante las tres campañas estivales consecutivas. 
8-11 $\mu \mathrm{g} / \mathrm{L} \mathrm{P}_{\text {total }}$ in the deep part (not shown). These data are in line with the value of $5 \mu \mathrm{g} / \mathrm{L}$ $\mathrm{P}_{\text {total }}$ reported by CHE (2013) and characterize Marboré as an ultra-oligotrophic system with strong P limitation for algal growth, which is common in high-altitude Pyrenean lakes (Catalán et al., 2006).

The sulfate concentration varied significantly between 2013 (12-17 mg/L SO $4^{2-)}$ and 2014 (1-2 $\mathrm{mg} / \mathrm{L} \mathrm{SO}_{4}^{2-;}$ Fig. 6d) and was negatively correlated with specific conductance. The higher concentration in the epilimnion in 2013 may suggest a near-surface source of dissolved sulfate, as discussed below.

\section{Total organic carbon}

The concentration of TOC is very low, ranging from $0.3 \mathrm{mg} / \mathrm{L}$ at depth in 2014 to $1.2 \mathrm{mg} / \mathrm{L}$ near the surface in 2015 (Fig. 6c). In 2014 and 2015, the TOC exhibited a relative enrichment in the epilimnion, suggesting a comparatively higher rate of biological production in the upper levels. It remains unknown whether this carbon enrichment results from an import of allochthonous carbon from the catchment or a weak algal bloom occurring soon after the ice cover melting.

\section{Trace metals}

Iron, zinc, aluminium and copper were, in decreasing order of concentration, the most abundant metals in the lake. Iron and zinc were especially enriched at a depth of $7 \mathrm{~m}$ in 2013 (Fig. 7), with peak concentrations of $4500 \mu \mathrm{g} / \mathrm{L} \mathrm{Fe}$ and $900 \mu \mathrm{g} / \mathrm{L} \mathrm{Zn}$, which are abnormally high for high mountain lakes in the Pyrenees and elsewhere (e.g., Bacardit \& Camarero, 2010). Aluminium and copper were also relatively enriched at the same depth, although to a minor extent (Fig. 7b, d). In a minor proportion, these relative enrichments in trace metals were also observed in 2014 and 2015. Therefore, this metal anomaly was not accidental and likely represents a common process in the lake.

The background concentrations of Fe and Zn at other depths were more typical, with ranges of 12-208 g/L Fe and 3-113 g/L Zn (Fig. 7). Thus, the input of dissolved metals seems to affect a very specific layer of the lake that roughly coincides with the thermocline (Fig. 3a). The sample taken from this depth in 2013 presented a greenish colour, which contrasted with the transparent nature of the rest of the samples. This water sample evolved during storage and handling in the laboratory, producing an orange precipitate that was filtered out and analysed (see inset in Fig. 8b). This precipitate was identified as ferrihydrite by XRD (not shown) and contained a high proportion of coprecipitated Zn (1.5 \%wt. Zn). Therefore, most of the iron content in the water corresponded to dissolved ferrous iron $\left(\mathrm{Fe}^{2+}\right)$.

\section{Mineral particles in water and snow}

\section{Suspended mineral particles in the water column}

The scarcity of algal remains observed in the filters was consistent with the low biological productivity and ultra-oligotrophy. Only very scattered green-coloured fibres and spherical diatoms $(\sim 5 \mu \mathrm{m})$ were detected. A marked contrast of particle density and colour was evidenced between the sample taken at $7 \mathrm{~m}$ depth (high density of particles, brownish colour) and those from other depths (low density and grey to yellow colour at 0 and $20 \mathrm{~m}$ ). The SEM study showed that these particles corresponded to different minerals including phyllosilicates (Fe-chlorite, biotite, kaolinite, illite) and quartz. Ore minerals, such as pyrite in the form of irregular crystal aggregates with diameters of 1-10 $\mu \mathrm{m}$, as well as lenticular crystals $(15 \mu \mathrm{m})$ of covellite, were also found. Sulfide alteration products were frequent, including Fe oxides and sulfate minerals, such as As-rich and $\mathrm{Pb}$-rich jarosite. The latter was usually present as pseudocubic crystals (1-2 $\mu \mathrm{m})$ or as aggregates (4-6 $\mu \mathrm{m})$ (Fig. 8a, b). EDS analyses conducted in jarosite crystals showed compositional ranges of $18-36 \% \mathrm{Fe}, 2-13 \% \mathrm{~Pb}$ and 2-4 \% As. The iron oxides were associated with clay minerals and exhibited irregular morphologies and significant $\mathrm{Pb}$ and As contents. Other minerals typical of supergenic alteration were observed, such as iron arsenates (e.g., scorodite).

The whole-sample chemistry of the filtrates (semiquantitative data obtained by XRF) included $\mathrm{SiO}_{2}, \mathrm{Al}_{2} \mathrm{O}_{3}, \mathrm{Fe}_{2} \mathrm{O}_{3}$ and $\mathrm{SO}_{3}$ as the major 

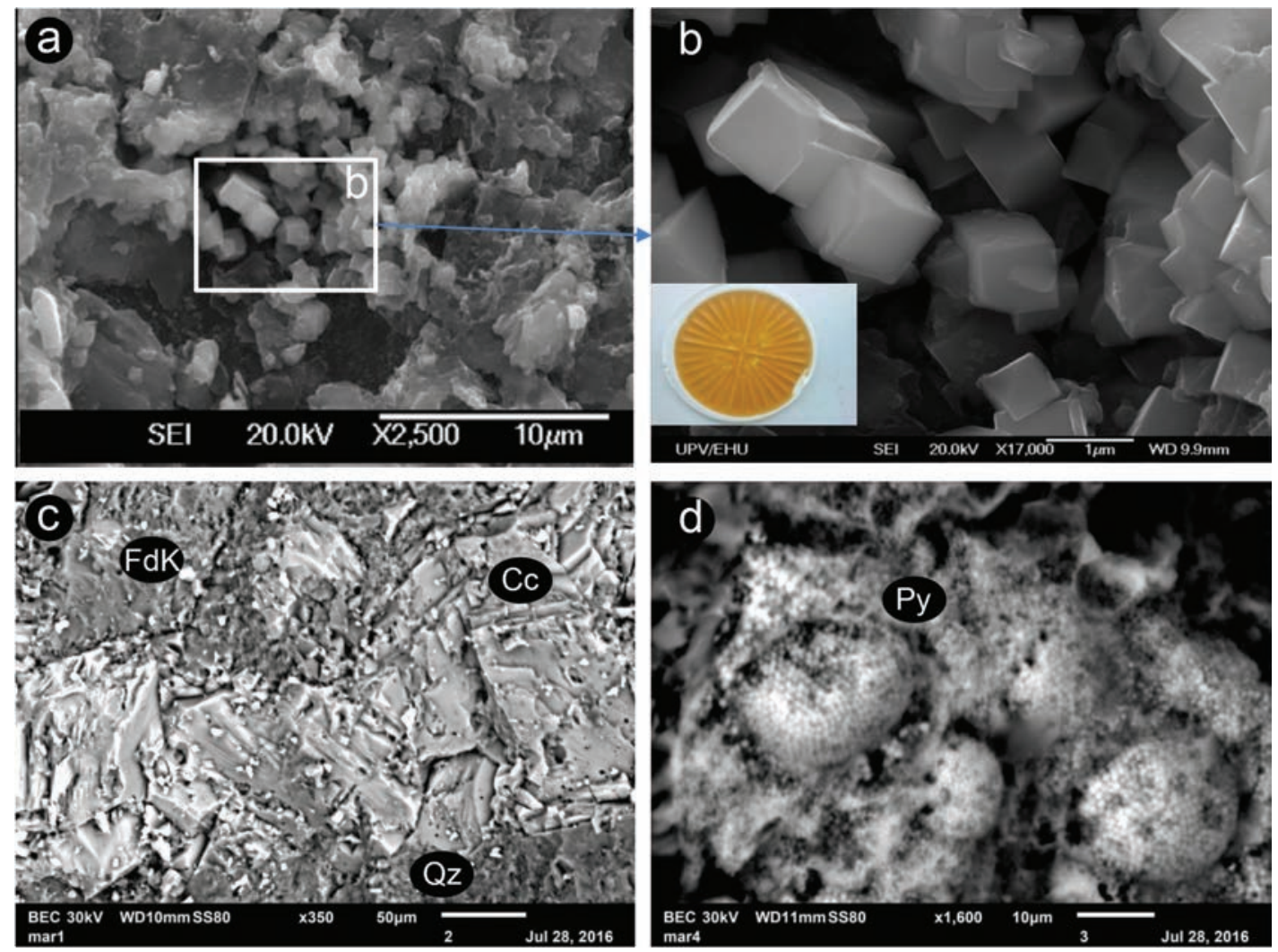

Figure 8. (a-b) SEM image of jarosite crystals found in the water column (7 m depth) of Lake Marboré in September 2013. The inset shows a membrane filter $(0.45 \mu \mathrm{m})$ after filtrating $250 \mathrm{~mL}$ of $\mathrm{Fe}(\mathrm{II})$-containing water from this depth, and stored two months in the laboratory. (c-d) Back-scattered electron images of rocks from Lake Marboré. Common calcite microveins occur with quartz (Qz), feldspars (KFd), micas and weathered framboidal pyrite (Py). Imágenes SEM de cristales de jarosita encontrados en la columna de agua (a 7 m de profundidad) del Lago Marboré en Septiembre de 2013. La pequeña foto interior a color muestra un filtro de membrana $(0.45 \mu \mathrm{m})$ después de filtrar $250 \mathrm{~mL}$ de agua con Fe(II) procedente de esta profundidad, y almacenada durante dos meses en el laboratorio. (c-d) Imágenes de electrones retro-dispersados de muestras de rocas presentes en el Lago Marboré. Se observan frecuentes microvenas de calcita con cuarzo (Qz), feldespatos (KFd), micas y pirita framboidal alterada (Py).

components (Table 1), which is in agreement with the abundance of quartz, clay minerals, and iron solids (oxides, sulfides and sulfates) in the waters. In addition, the sample from $7 \mathrm{~m}$ presented very high concentrations of $\mathrm{Zn}$ (950 ppm) and As (1000 ppm), which were presumably contained in the sulfides and sulfates (e.g., jarosite) (Table 1).

\section{Mineral particles in snow}

Mineral particles found in snow samples taken from the lake surroundings corresponded to silicates and aluminosilicates (quartz, feldspar, and clay minerals). No evidence of metal-con- taining phases (e.g., sulfides, oxides) was found in these samples. A few samples of dust-containing snow were chemically analysed, and several metals ( $\mathrm{Fe}, \mathrm{Al}, \mathrm{Mn}, \mathrm{Zn}$ ) were detected at low concentrations (Table 2). The TOC in this snow was approximately $1 \mathrm{mg} / \mathrm{L}$.

\section{DISCUSSION}

\section{Interannual evolution of $\mathrm{pH}$ and epilimnetic temperature}

The $\mathrm{pH}$ values obtained in this study (Fig. 5c) are notably lower than those measured during a monitoring programme conducted by the Ebro Hydro- 
Table 1. Chemical composition of suspended particulate matter ( $>0.45 \mu \mathrm{m}$ ) sampled at different depths through the water column in Lake Marboré in September 2013. Composición química de la materia particulada en suspensión (>0.45 $\mu \mathrm{m}$ ) muestreada a diferentes profundidades en la columna de agua del Lago Marboré en septiembre de 2013.

\begin{tabular}{lcccccc}
\hline Depth & $\mathrm{SiO}_{2}$ & $\mathrm{Al}_{2} \mathbf{O}_{3}$ & $\mathrm{Fe}_{2} \mathbf{O}_{3}$ & $\mathbf{S O}_{3}$ & $\mathbf{Z n}$ & As \\
$m$ & $w t . \%$ & $w t . \%$ & $w t . \%$ & $w t . \%$ & $p p m$ & $p p m$ \\
0 & 2.3 & 1.5 & 0.2 & 0.4 & 0 & 0 \\
7 & 7.6 & 5.0 & 1 & 1.7 & 950 & 1000 \\
20 & 2.2 & 1.5 & 0.3 & 0.1 & 915 & 0 \\
\hline
\end{tabular}

logical Authority: 8.6 in 2007, 7.6 in 2008 and 8.2 in 2012-2013, with all values presumably corresponding to the lake surface (CHE, 2013). We checked for $\mathrm{pH}$ heterogeneities throughout the lake in all campaigns. Measurements of $\mathrm{pH}$ in the lake shore only differed in around $0.1 \mathrm{pH}$ units with respect to those recorded in the lake centre, which is close to the instrumental uncertainty. Thus, we do not think this can explain the difference in $\mathrm{pH}$ readings with respect to $\mathrm{CHE}$ measurements. We did not check, however, for intra-day variations of $\mathrm{pH}$ in a given part of the lake, which can occur as a response to changes in the balance between respiration and photosynthesis (Wetzel, 2001).

In any case, the series of measurements is still short and does not allow for the establishment of a clear pattern. In addition, the month of September in mountain lakes is usually a rather dynamic month, during which the speed of thermocline deepening, and thus the vertical profiles of the physicochemical parameters, may change daily (e.g., Catalán et al., 2002). The thermocline is usually weaker during this time of the year, and this effect should be considered in the interpretation of results. Monitoring measurements should be considered and investigated in future studies to detect a possible acidification process in Lake Marboré.

Groundwater of the Ordesa and Monte Perdido National Park usually exhibits $\mathrm{pH}$ values between 7.7 and 8.5 and calcium-bicarbonate compositions (Lambán et al., 2015), characteristic of karstic systems. On the other hand, high mountain lakes in the Pyrenees and Central Range
Table 2. Chemical composition of dust-containing snow accumulated around Lake Marboré (September 2013). Composición química de la nieve con contenido en polvo acumulada en el entorno del Lago Marboré (septiembre de 2013).

\begin{tabular}{lcccccc}
\hline $\mathrm{NO}_{3}{ }^{-}$ & TOC & TIC & $\mathbf{F e}$ & $\mathrm{Al}$ & $\mathbf{M n}$ & $\mathrm{Zn}$ \\
$\mathrm{mg} / \mathrm{L}$ & $\mathrm{mg} / \mathrm{L}$ & $\mathrm{mg} / \mathrm{L}$ & $\mu g / L$ & $\mu g / L$ & $\mu g / L$ & $\mu g / L$ \\
0 & 1.1 & 1.8 & 44 & 41 & 13 & 8 \\
\hline
\end{tabular}

of the Iberian Peninsula usually display circumneutral to slightly acidic $\mathrm{pH}$ values (6.0-7.0) and very low conductivities (e.g., Bacardit \& Camarero, 2010; Toro et al., 2006). These lakes are usually fed by meltwaters with very low mineralization and a weak buffer capacity, and they are therefore sensitive to environmental changes (Battarbee et al., 2002; Catalán et al., 2006; Camarero, 2013). Whether the observed trend of apparently decreasing $\mathrm{pH}$ in Lake Marboré is related to some global or regional climatic factor (e.g., longer ice-free periods leading to enhanced meteoric alteration and/or higher rates of sediment transport) should be evaluated when longer $\mathrm{pH}$ time series are available.

Anthropogenic acidification of lakes is usually related with factors such as (i) acid rain (including dry deposition) and/or (ii) burning of fossil fuels (especially coal). The major acid substance is often $\mathrm{SO}_{2}\left(\mathrm{H}_{2} \mathrm{SO}_{4}\right)$, though nitrous oxides $\left(\mathrm{HNO}_{3}\right)$ and chlorides $(\mathrm{HCl})$ also have an impact (Hellström, 2012). These substances emitted as gases can be transported long distances until they reach remote mountain lakes (Battarbee, 2005; Curtis et al., 2005). In a survey of 102 lakes in the Pyrenees (Camarero \& Catalán, 1998), $68 \%$ of these lakes were found to be sensitive to acidification in varying degrees. These authors proposed a model describing the regional alkalinity distribution by using random variables to represent lake alkalinity, chemical weathering and biological alkalinity generation. According to this model, Camarero \& Catalán (1998) calculated that a $50 \%$ reduction of both nitrogen and sulphur deposition would be necessary to avoid severe acidification of Pyrenean lakes. The lack of historical records on $\mathrm{S}$ and $\mathrm{N}$ concentration in Lake Marboré does not allow the establishment of temporal trends of these acid agents in this 

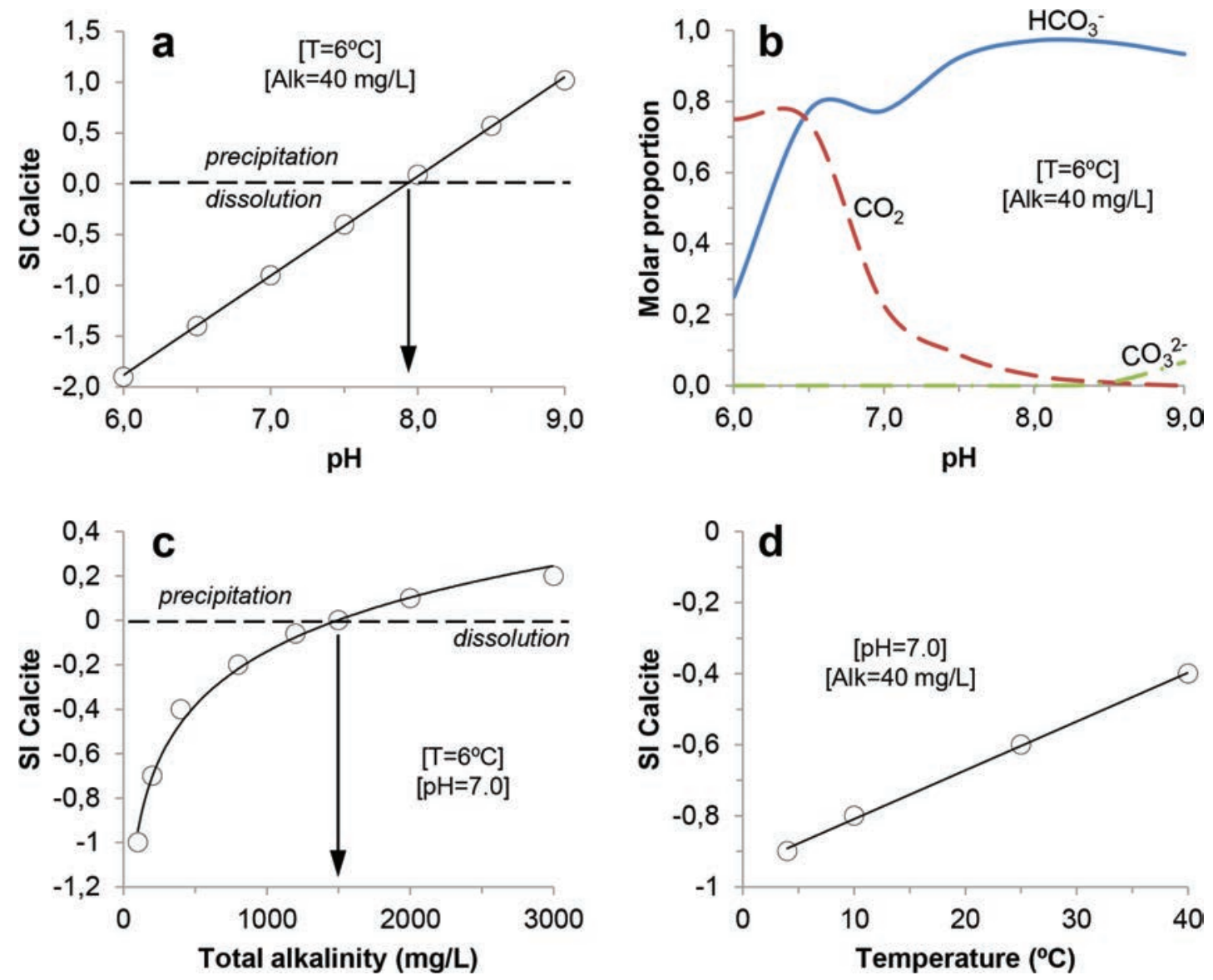

Figure 9. Binary plots showing the saturation index (SI) of calcite against $\mathrm{pH}$ (a), total alkalinity (c), and temperature (d), and a variation of different dissolved inorganic carbon species with $\mathrm{pH}$ (b) in Lake Marboré. Calculations computed with PHREEQCI using chemical data from September 2013. Diagramas binarios mostrando el índice de saturación (SI) de la calcita frente al pH (a), alcalinidad total (c), and temperatura (d), y variación de las diferentes especies de carbono inorgánico disuelto en función del pH (b) en el Lago Marboré. Cálculos efectuados con PHREEQCI usando datos químicos obtenidos en septiembre de 2013.

lake, nor their possible influence on the $\mathrm{pH}$. The study of sulfur and nitrogen concentration and speciation is therefore important and should be included in any future research addressing the possible acidification of this lake.

An important implication of the measured $\mathrm{pH}$ in Lake Marboré corresponds to the speciation of DIC and the stability of calcite (Fig. 9). Geochemical calculations indicate that the chemical variable that most clearly affects the solubility of $\mathrm{CaCO}_{3}$ is $\mathrm{pH}$ (Fig. 9a). With the present-day alkalinity (40 mg/L), calcite saturation and precipitation would not occur if the $\mathrm{pH}$ were below 8.0. Therefore, the whole water column remained undersaturated with respect to calcite during the study period. Calcite is therefore unstable in the lake and tends to dissolve. The total alkalinity ( bicarbonate concentration) and the water temperature do not seem to be relevant variables in this case (Fig. 9c-d). Fluctuations in calcite abundance in the sedimentary record would therefore be possible due to seasonal or long-term variations in the $\mathrm{pH}$ in the water column. This pattern seems to be in line with the findings of Oliva-Urcia et al. (2009, 2013), who noted the vertical scarcity and variation in calcite abundance (sporadic levels with calcite) in sediment cores from Lake Marboré, despite calcite being abundant in the catchment. The $\mathrm{pH}$ values measured around the thermocline (Fig. 
5c), where primary production is usually higher in oligotrophic mountain lakes (Pla-Rabes \& Catalan 2011; Ventura et al., 2000) are not too far from values of calcite precipitation (Fig. 9a), which may explain why calcite has been be found in Marbore sediment records. This variability associated to primary production could explain Oliva-Urcia et al. (2009, 2013) observations.

The graph in Fig. 9b also illustrates that between 10 and $20 \%$ (in molar proportion) of the DIC is present at the prevailing $\mathrm{pH}$ at depth (7.1-7.4; Fig. 5c) in the form of $\mathrm{CO}_{2}$ (aq.). The remainder is bicarbonate $\left(\mathrm{HCO}_{3}^{-}\right)$. The observed TDG increase (Fig. 5d) thus corresponds to local increases in $\mathrm{CO}_{2}$, either by calcite dissolution and/or microbial respiration at depth.

The short temperature data series of only 3 years does not allow for the establishment of a clear conclusion about the thermal dynamics of the lake. On the one hand, both the maximum temperature recorded in the surface layer $(0.5 \mathrm{~m})$ and the sharpness and/or duration of the thermal stratification during the ice-free period have apparently increased during the studied period, which is likely an immediate effect of local-regional climatic fluctuations (Fig. 3). On the other hand, the temperature of the deepest water did not change significantly during the long ice-covered period and stayed within the $2.5-3.5^{\circ} \mathrm{C}$ interval. The data series is still too short to demonstrate a warming of the epilimnion in the summer as a response to increasing air temperatures at the regional scale. However, the evident melting and retreat of the Monte Perdido Glacier (López-Moreno 2005, López-Moreno et al., 2015) is straightforward evidence of global warming, which could also induce a rapid decrease in the thickness of the winter ice cover of Lake Marboré. The future evolution of the thickness and duration of the ice cover may have important consequences for the thermal regime, chemical evolution and ecology of the lake, and these climate-derived effects should be monitored and studied in upcoming years.

\section{Trace metals: sources and implications}

Chemical analyses of sediment cores taken along a N-S transect of the Marboré basin (Salabar- narda, 2011, Oliva-Urcia et al., 2013, Mata et al., 2013) have shown enrichments in several trace metals (Fe, As, $\mathrm{Pb}, \mathrm{Cd}, \mathrm{Zn}, \mathrm{Cu}$ ). The highest values of Fe-As were related to a layer of iron oxy-hydroxides, whereas enrichments in $\mathrm{Zn}, \mathrm{Cu}$ and Cd were all present at the top of the sequence (modern times). Atmospheric deposition is an important source of trace metals in alpine lakes (Camarero et al., 2009; Bacardit \& Camarero, 2010), and the Holocene sedimentary records of many mountain lakes in the Iberian Peninsula have shown a clear increase in trace metal content with the initiation of mining activities during the Bronze and Copper Ages and especially during the Roman Age (Martínez et al., 2013, Mata et al., 2013). This pattern is very similar to that shown for acidification of lakes, which suggests that these metals and the pollutants responsible for acidification (i.e., usually $\mathrm{S}$ and $\mathrm{N}$ compounds) have a common origin, generally from industrial sources and more specifically from the combustion of fossil fuel elsewhere in most regions of Europe even those remote from industrial source regions (Battaerbee, 2005).

However, different studies have shown that trace metal enrichments in alpine lakes can also result from rock weathering in the catchment. Camarero et al. (1998) reported lead pollution in a Pyrenean lake that resulted from historical, long-distance pollution and from local sources. Catalán et al. (2014) have recently shown a connection between climate warming and rock weathering in the form of a rapid response of the lake chemistry to these climatic changes.

In the case of Marboré, the high Zn values and their correlation with $\mathrm{Cd}$ and $\mathrm{Cu}$ point to local sources, most likely the oxidation and dissolution of sulfides such as sphalerite, which may contain trace amounts of $\mathrm{Cd}$ and $\mathrm{Cu}$ (e.g., Sánchez-España, 2000). The apparent increase in the $\mathrm{Cd} / \mathrm{Al}$, $\mathrm{Cu} / \mathrm{Al}$ and $\mathrm{Zn} / \mathrm{Al}$ ratios along the lake sedimentary sequence (Mata et al., 2013) and in the water column might be related to an increase of weathering processes in the lake basin due to changes in the climatic conditions of the area (e.g., increase in temperature and thawing of the ice cover). Thus, the high $\mathrm{Zn}$ values found in the water column (thermocline) in 2014 appear to result from weathering reactions involving sulfides, as 
detected in the sediments since ancient times. The presence of dissolved ferrous iron and sulfate in the water sample at $7 \mathrm{~m}$, the molar ratio between these two ions ([Fe/S] $\sim 0.5$, typical of pyrite, $\mathrm{FeS}_{2}$ ), and the observation of jarosite (typical alteration product of pyrite oxidation), are all indirect evidence of oxidative dissolution of sulfide minerals (mostly pyrite but also minor sphalerite and galena) occurring in the lake basin. $\mathrm{Fe}, \mathrm{SO}_{4}$ and $\mathrm{Zn}$ likely enter the lake via the subsurface or shallow underground flow.

\section{CONCLUSIONS AND FINAL COMMENTS}

A comparison of the data shown in this work with previous results of the surface water suggests an apparent acidification of the lake. A systematic $\mathrm{pH}$ control in Marboré is thus recommended to determine if acidification is occurring in the system.

Although the host rock mineral composition has a clear influence on the dissolved trace metal content, additional samplings of the water column compared with climatic series will allow us to confirm if episodes of sulfate and metal input are related to an intensification of weathering reactions in the area due to global change.

A permanent temperature recording by thermistors will allow us to identify the relationship between air and lake water temperature. This monitoring will help with the analysis of climatic trends at the local scale, as well as the consequences of global warming on lake dynamics. This information will be important for designing rational and efficient protection for the lake.

\section{ACKNOWLEDGEMENTS}

This work was funded by Organismo Autónomo de Parques Nacionales through project CLAM-1 ("Evaluación y seguimiento del cambio global en tres lagos de alta montaña: Enol, Marboré y la Caldera. Indicadores físico-químicos"; Ref. number 533S/2012). SEM and XRF analyses were conducted at the IGME laboratories and the SGIker Facilities (UPV/EHU). This work is dedicated to Professor Maria Rieradevall (University of Barcelona), who promoted and supported this project and who sadly passed away on October
2015. We thank the staff of the Ordesa and Monte Perdido National Park for the support provided in the field campaigns.

\section{REFERENCES}

ANSELMETTI F.S., R. BÜHLER, D. FINGER, S. GIRARDCLOS, A. LANCINI, C. RELLSTAB \& M. STURM. 2007. Effects of Alpine hydropower dams on particle transport and lacustrine sedimentation. Aquatic Sciences, 69:179-198. DOI: https://doi.org/10.1007/ s00027-007-0875-4

ARNAUD, F., M. REVEL-ROLLAND, D. BOSCH, T. WINIARSKI, E. CHAPRON, M. DESMET, N. TRIBOVILLARD \& N. GIVELET. 2004. A reliable 300 years-long history of lead contamination in Northern French Alps from distant lake sediment records. Journal of Environmental Monitoring, 6: 448-456.

BACARDIT, M. \& L. CAMARERO. 2010. Modelling $\mathrm{Pb}, \mathrm{Zn}$ and As transfer from terrestrial to aquatic ecosystems during the ice-free season in the Pyrenean catchments. Science of the Total Environment, 408: 5854-5861. DOI: https://doi.org/10.1016/j.scitotenv.2010.07. 088

BATTARBEE, R.W. 2005. Mountain lakes, pristine or polluted? Limnetica, 24(1-2): 1-8.

BATTARBEE, R.W., R. THOMPSON, J. CATALÁN, J.A. GRYTNES \& H.J.B. BIRKS. 2002. Climate variability and ecosystem dynamics of remote alpine and arctic lakes: the MOLAR project. Journal of Paleolimnology, 28: 1-6. DOI: https://doi.org/10. 1023/A:1020342316326

BOEHRER, B. 2012. Double-Diffusive Convection in Lakes. In: Encyclopedia of Lakes and Reservoirs (L. Bengtsson, R.W. Herschy \& R.W. Fairbridge, Eds.). Springer Netherlands. pp. 223-224.

CAMARERO L. 2013. Lagos alpinos: Observatorios del cambio global. Investigación y Ciencia, 443, 52-58

CAMARERO, L., I. BOTEV, G. MURI, R. PSENNER, N. ROSE \& E. STUCHLIK. 2009. Trace elements in alpine lake sediments as a record of diffuse atmospheric contamination across Europe. Freshwater Biology, 54: 
2518-2532. DOI: 10.1111/j.1365-2427.2009. 02303.x

CAMARERO L. \& J. CATALÁN. 1998. A simple model of regional acidification for high mountain lakes: application to the Pyrenean lakes (North-East Spain). Water Research, 324:1126-1136. DOI: https://doi.org/10.1016/ S0043-1354(97)00291-1

CAMARERO, L., P. MASQUÉ, W. DEVOS, I. ANI-RAGOLTA, J. CATALÁN, H.C. MOOR, S. PLA \& J.A. SÁNCHEZ-CABEZA. 1998. Historical variations in lead fluxes in the Pyrenees (Northeast Spain) from a dated lake sediment core. Water, Air, and Soil Pollution, 105:439-449. DOI: https://doi.org/10.1023/A:1005005625972

CATALÁN J., E. BALLESTEROS, E. GACIA, A. PALAU \& L. CAMARERO. 1993. Chemical composition of disturbed and undisturbed high-mountain lakes in the Pyrenees: A reference for acidified sites. Water Research, 27-1: 133-141. DOI: https://doi.org/10.1016/00431354(93)90203-T

CATALÁN, J., M. VENTURA, A. BRANCELJ, I. GRANADOS, H. THIES, U. NICKUS, A. KORHOLA, A.F. LOTTER, A. BARBIERI, E. STUCHLIK, L. LIEN, P. BITUŠIK, T. BUCHACA, L. CAMARERO, G.H. GOUDSMIT, J. KOPÁĆEK, G. LEMCKE, D.M. LIVINGSTONE, B. MÜLLER, M. RAUTIO, M. ŠIŠKO, S. SORVARI, F. ŠPORKA, O. STRUNECKÝ \& M. TORO. 2002. Seasonal ecosystem variability in remote mountain lakes: implications for detecting climatic signals in sediment records. Journal of Paleolimnology, 28: 25-46. DOI: https://doi.org/10. 1023/A:1020315817235

CATALÁN, J., L. CAMARERO, S. FELIP, M. VENTURA, T. BUCHACA, F. BARTUMEUS, G. DE MENDOZA, A. MIRÓ, E.O. CASAMAYOR, J.M. MEDINA-SÁNCHEZ, M. BACARDIT, M. ALTUNA, M. BARTRONS \& D. DÍAZ DE QUIJANO. 2006. High mountain lakes: extreme habitats and witnesses of Environmental changes. Limnetica, 25(1-2): 551-584

CATALÁN, J., S. PLA-RABÉS, A.P. WOLFE, J.P. SMOL, K.M. RÜHLAND, N.J. ANDERSON, J. KOPÁČEK, E. STUCHLÍK, R.
SCHMIDT, K.A. KOINIG, L. CAMARERO, R.J. FLOWER, O. HEIRI, C. KAMENIK, A. KORHOLA, P.R. LEAVITT, R. PSENNER \& I. RENBERG. 2013. Global change revealed by palaeolimnological records from remote lakes: A review. Journal of Paleolimnology, 49: 513-535. DOI: https://doi.org/10. 1007/s10933-013-9681-2

CATALÁN, J., S. PLA-RABÉS, J. GARCÍA \& L. CAMARERO. 2014. Air temperature-driven $\mathrm{CO} 2$ consumption by rock weathering at short timescales: Evidence from a Holocene lake sediment record. Geochimica et Cosmochimica Acta, 136: 67-79. DOI: https://doi.org/10.1016/j.gca.2014.04.005

CONFEDERACIÓN HIDROGRÁFICA DEL EBRO. 2006. Establecimiento de condiciones de referencia y redefinición de redes en la cuenca del Ebro, según la Directiva 2000/60/CE (Expediente n ${ }^{\circ}$ 27/04-A). 52 pp.

CONFEDERACIÓN HIDROGRÁFICA DEL EBRO. 2013. Diseño y explotación de la red de seguimiento de lagos en la cuenca del Ebro, 232 pp. (available at http://www.chebro.es).

CURTIS, C.J., I. BOTEV, L. CAMARERO, J. CATALAN, D. COGALNICEANU, $M$. HUGHES, M. KERNAN, J. KOPÁČEK, A. KORHOLA, R. PSENNER, M. ROGORA, E. STUCHLÍK, M. VERONES \& R. WRIGHT. 2005. Acidification in European mountain lake districts: A regional assessment of critical load exceedance. Aquatic Sciences, 67(3):237-251. DOI: https://doi.org/10.1007/ s00027-005-0742-0

GARCÍA-RUIZ, J.M., D. PALACIOS, N. DE ANDRÉS, B.L. VALERO-GARCÉS, J.I. LÓPEZ-MORENO \& Y. SANJUÁN. 2014. Holocene and "Little Ice Age” glacial activity in the Marboré Cirque, Monte Perdido Massif, Central Spanish Pyrenees. The Holocene, 24(11): 1439-1452. DOI: https://doi.org/10. 1177/0959683614544053

GARCÍA-RUIZ, J.M., D. PALACIOS, P. GONZÁLEZ-SAMPÉRIZ, N. DE ANDRÉS, A. MORENO, B. VALERO-GARCÉS \& A. GÓMEZ-VILLAR. 2016. Mountain glacier evolution in the Iberian Peninsula during the Younger Dryas. Quaternary Science Reviews, 138: 16-30. DOI: https://doi.org/10.1016/ 
j.quascirev.2016.02.022

HELLSTRÖM, T. 2012. Acidification in Lakes. In: Encyclopedia of Lakes and Reservoirs (L. Bengtsson, R.W. Herschy \& R.W. Fairbridge, Eds.), Springer Netherlands, p. 1 HERNÁNDEZ-PACHECO, F. \& C. VIDAL-BOX. 1946. La tectónica y la morfología del macizo de Monte Perdido y de las zonas de cumbres inmediatas en el Pirineo Central. Pirineos, 4: 69-108.

LAMBÁN, L.J., J. JÓDAR, E. CUSTODIO, A. SOLER, G. SAPRIZA \& R. SOTO. 2015. Isotopic and hydrogeochemical characterization of high-altitude karst aquifers in complex geological settings. The Ordesa and Monte Perdido National Park (Northern Spain) case study. Science of the Total Environment, 506-507: 466-479. DOI: https://doi.org/10. 1016/j.scitotenv.2014.11.030

LÓPEZ-MORENO, J.I. 2005. Recent variations of snowpack depth in the Central Spanish Pyrenees. Arctic, Antarctic \& Alpine Research, 37: 253-260. DOI: https://doi.org/ 10.1657/1523-0430(2005)037[0253:RVOSDI] 2.0.CO;2

LÓPEZ-MORENO, J.I., J. REVUELTO, I. RICO, J. CHUECA-CÍA, A. JULIÁN, A. SERRETA, E. SERRANO, S.M. VICENTE-SERRANO, C. AZORÍN-MOLINA, E. ALONSO-GONZÁLEZ \& J.M. GARCÍA-RUIZ. 2015. Accelerated wastage of the Monte Perdido Glacier in the Spanish Pyrenees during recent stationary climatic conditions. The Cryosphere Discussions, 9: 5021-5051. DOI: https://doi.org/10.5194/tc-10-681-2016

MAHOWALD, N. 2011. Aerosol indirect effect on biogeochemical cycles and climate. Science, 334: 794-796. DOI: https://doi.org/ 10.1126/science.1207374

MARTÍNEZ, A., L. LÓPEZ-MERINO, R. BINDLER, T. MIGHALL \& M. KYLANDER. 2013. Atmospheric $\mathrm{Pb}$ pollution in $\mathrm{N}$ Iberia during the late Iron Age/Roman times reconstructed using the high-resolution record of $\mathrm{La}$ Molina mire (Asturias, Spain). Journal of Paleolimnology, 50: 71-86. DOI: https://doi.org/10. 1007/s10933-013-9705-y

MATA, P., A. MORENO, B. OLIVA-URCIA, B. VALERO-GARCÉS \& T. RICO. 2013.
Registro histórico de la contaminación atmosférica por $\mathrm{Pb}$ en el lago de Marboré (P.N. de Ordesa y Monte Perdido). Macla, 1: 71-72.

MOOIJ, W.M., J.H. JANSE, L.N. DE SENERPONT DOMIS, S. HÜLSMANN \& B.W. IBELINGS. 2007. Predicting the effect of climate change on temperate shallow lakes with the ecosystem model PCLake. Hydrobiologia, 584: 443-454. DOI: https://doi.org/10. 1007/s10750-007-0600-2

NICOLÁS-MARTÍNEZ, P.M. 1981. Morfología del circo de Tucarroya (Macizo Monte Perdido, Pirineo Aragones). Cuadernos de Investigación Geográfica, 7: 51-80.

OLIVA-URCIA, B., J.C. LARRASOAÑA, E.L. PUEYO, A. GIL, P. MATA, J.M. PARÉS, A.M. SCHLEICHER \& O. PUEYO. 2009. Disentangling magnetic subfabrics and their link to deformation processes in cleaved sedimentary rocks from the Internal Sierras (west central Pyrenees, Spain). Journal of Structural Geology, 31: 163-176. DOI: https://doi.org/10.1016/j.jsg.2008.11.002

OLIVA-URCIA, B., A. MORENO, B. VALERO-GARCÉS, P. MATA, GRUPO HORDA. 2013. Magnetismo y cambios ambientales en registros terrestres: el lago de Marboré, Parque Nacional de Ordesa y Monte Perdido (Huesca). Cuadernos de Investigación Geográfica, 39: 117-140

PLA-RABES, S. \& J. CATALÁN. 2011. Deciphering chrysophyte responses to climate seasonality. Journal of Paleolimnology, 46: 139-150. DOI: https://doi.org/10.1007/s10933011-9529-6

ROZANSKI, K., L. ARAGUÁS-ARAGUÁS \& R. GONFIANTINI. 1993. Isotopic patterns in modern global precipitation. In Swart, P.K., et al. (Eds.) Climate changes in continental isotopic records, Geophysical Monograph No 78, Washington, American Geophysical Union, p. 1-36. DOI: 10.1029/GM078p0001

SALABARNADA, A. 2011. Recent depositional evolution of a high altitude, Alpine lake: Marboré lake (Ordesa-Monte Perdido National Park, Spanish Pyrenees). MSc thesis, CSIC-UIMP, $42 \mathrm{pp}$.

SÁNCHEZ-ESPAÑA, J. 2000. Mineralogía y geoquímica de yacimientos de sulfuros 
masivos en el área nor-oriental de la Faja Pirítica Ibérica (San Telmo-San Miguel-Peña del Hierro), Norte de Huelva, España. PhD Thesis, Universidad del País Vasco, UPV/EHU, Bilbao, 307 pp.

SICKMAN, J. O., J.M. MELACK, \& D.W. CLOW. 2003. Evidence for nutrient enrichment of high-elevation lakes in the Sierra Nevada, California. Limnology \& Oceanography, 48:1885-1892. DOI: http://dx.doi.org/10. 4319/lo.2003.48.5.1885

THÉVENON, F., N.D. GRAHAM, M. CHIARADIA, P. ARPAGAUS, W. WILDI \& J. POTÉ. 2011. Local to regional scale industrial heavy metal pollution recorded in sediments of large freshwater lakes in central Europe (lakes Geneva and Lucerne) over the last centuries. Science of the Total Environment, 412-413: 239-247. DOI: https://doi.org/10.1016/j. scitotenv.2011.09.025

TORO, M., I. GRANADOS, S. ROBLES \& C. MONTES. 2006. High mountain lakes of the
Central Range (Iberian Peninsula): Regional limnology \& Environmental changes. Limnetica, 25(1-2): 217-252.

VENTURA, M., L. CAMARERO, T. BUCHACA, F. BARTUMEUS, D.M. LIVINGSTONE \& J. CATALÁN. 2000. The main feature of seasonal variability in the external forcing and dynamics of a deep mountain lake (Redo, Pyrenees). Journal of Limnology, 59: 97-108. DOI: https://doi.org/10.4081/jlimnol. 2000.s1.97

WATHNE, B., S. PATRICK \& N. CAMERON. 1997. AL:PE - Acidification of mountain lakes: Palaeolimnology and ecology. Part 2 Remote mountain lakes as indicators of air pollution and climate change. NIVA Rapport 3638, Norsk Institutt for Vannforskning. 529 pp. (Available at http://hdl.handle.net/11250/ 209324)

WETZEL, R.G. 2001. Limnology: lake and River Ecosystems. Academic Press, 1-850 pp. 